\title{
NATURAL DIET OF LIGIA EXOTICA (CRUSTACEA, ISOPODA, LIGIIDAE) IN TWO ESTUARINE REGIONS OF PATOS LAGOON, RIO GRANDE DO SUL, BRAZIL.
}

ELIS REGINA LOPES-LEITZKE, CAMILA WALLY DA SILVA E SOUZA MACEDO, DEISE AZEVEDO LONGARAY \& FERNANDO D'INCAO

Universidade Federal do Rio Grande (FURG), Instituto de Oceanografia, Laboratório de Crustáceos Decápodos, CP: 474, CEP: 96.201-900 Rio Grande, RS, Brasil, email: elisleitzke@gmail.com.

\section{RESUMO \\ Dieta natural de Ligia exotica (Crustacea, Isopoda, Ligiidae) em duas regiões do estuário da Lagoa dos Patos,} Rio Grande do Sul, Brasil

Isópodos são exemplos da transição evolutiva dos crustáceos do mar para terra, existindo formas tipicamente aquáticas e formas tipicamente terrestres. Ligia exotica é dominante na região intertidal do Estuário da Lagoa dos Patos, tendo um importante papel na reciclagem de nutrientes e na cadeia trófica. A área de estudo compreendeu o Molhe Oeste de Rio Grande e a llha do Leonídeo. O conteúdo alimentar foi estudado sazonalmente, através da captura manual de indivíduos em Outubro/2003, Janeiro, Abril e Julho/2004. Após capturados, os indivíduos foram fixados imediatamente em formol $4 \%$ durante 24 horas e conservados em álcool $70 \%$. Os tubos digestivos foram pesados e o grau de repleção foi estimado. O conteúdo de cada tubo digestivo foi diluído em $1 \mathrm{ml}$ de água destilada. Para quantificação dos itens, o conteúdo foi colocado em uma lâmina de contagem graduada. Cada item identificado foi quantificado pela contagem do número de ocorrência nos quadrados da lâmina. Para testar a possível diferença entre a frequência dos itens consumidos por machos e fêmeas, foi utilizado o quiquadrado. Análises qualiquantitativas foram realizadas segundo os métodos de freqüência relativa de ocorrência, freqüência relativa dos pontos. Um total de 912 tubos digestivos foi analisado: 426 indivíduos no Molhe Oeste e 485 indivíduos na llha do Leonídeo. Seis itens alimentares foram identificados e diferenças significativas foram observadas nos itens consumidos por machos e fêmeas de ambas as populações. Os itens alimentares mais importantes para a dieta natural de Ligia exotica foram: detrito vegetal, areia e a alga Polysiphonia sp. Desta forma, em ambas as regiões do estuário, a espécie pode ser considerada generalista.

PALAVRAS CHAVE: Oniscidea, Ligia exotica, alimentação, dinâmica populacional, Estuário da Lagoa dos Patos

\section{ABSTRACT}

Isopods are examples of the evolutive transition of the crustaceans from sea to land, inhabiting aquatic and terrestrial environments. Ligia exotica is dominant in the intertidal region of the of Patos Lagoon estuary, playing an important role in recycling nutrients and in the trophic web as a whole. The study area was the West Breakwater of Rio Grande Channel and Leonideo Island. The natural diet was analyzed through standardized one hour manual sampling performed in October/2003, January, April and July/2004. After collected, individuals were immediately fixed in $4 \%$ formalin during 24 hours and conserved in $70 \%$ ethanol. The guts were weighted and repletion degree was estimated. Each gut content was diluted in $1 \mathrm{ml}$ of distilled water. To quantify the items, content was placed in a graduated slide for counting. Each identified item was quantified by the number of occurrences in the slide squares. To test significant differences between the frequencies of items consumed by males and females, a chi-square test was used. Qualiquantitative analysis was performed following the method of relative frequency of occurrence and relative frequency of points. A total of 912 guts was analyzed: 426 individuals from the West Breakwater and 485 individuals from the Leonideo Island. Six food items were identified and significant differences were observed in the items consumed by males and females of both populations. The most important food items in the natural diet of Ligia exotica were: vegetal detritus, sand and the seaweed Polysiphonia sp. Thus, in both regions of the Estuary, the species can be considered generalist.

KEYWORDS: Oniscidea, Ligia exotica, feeding, population dynamics, Estuary of Patos Lagoon

\section{INTRODUCTION}

Isopods are examples of the evolutionary transition of the crustaceans from sea to land, inhabiting both, aquatic and terrestrial environments. A total of 12000 species are recorded in the literature, of which 3600 belong to Suborder Oniscidea and are present in a variety of habitats, such as beaches, salt marshes, forests and deserts (CAREFOOT \& TAYLOR 1995; SCHMALFUSS 2003).

Section Diplochaeta, which includes the Family Ligiidae, represents the most basal lineage within the Oniscidea (ERHARDT 1997) and includes the genus Ligia Fabricius, 1798 and Ligidium Brandt, 1833. Approximately 30 species of the genus Ligia are spread throughout the world, mostly restricted to supralitoral environments. Its distribution extends up vertically a few meters below the highest level of the tide, where algae and fouling diatoms are brought by the tides (CAREFOOT et al. 2000).

Ligia exotica Roux, 1828, is widely distributed along the temperate and hot areas. In the American continent it is found from North Carolina to Southern Brazil and from California to Chile (LEMOS DE CASTRO 1971). Two other species occur in Brazil, named $L$. baudiniana Milne-Edwards, 1840 and $L$. olfersii Brandt, 1933 (SOUZA-KURY 1998).

Semi-terrestrial isopods are important components of the intertidal fauna, feeding decomposed vegetation or the seaweed that grow in this area (SCHULTZ 1977). Detritivorous feeding is considered an important agent in the ecosystem transference of energy (SUTTON 1980), being the largest representative of the fauna of many coastal environments (SHEADER 1977). 
SOUZA (1998) points L. exotica as an important element in the recycling and mineralization of natural and anthropogenic organic matter.

Ligia species are white common in nutrition and consumption of oxygen studies (CAREFOOT 1984; 1987a; 1987b; 1989; CAREFOOT et al. 1992; 1998; 2000). However, analyses of natural diet were never accomplished for L. exotica. CAREFOOT (1973) analyzed the natural diet and the food preference of $L$.

\section{MATERIAL AND METHODS}

The estuarine area of Patos Lagoon is characterized by shallow water bays and numerous islands (CORDAZZO \& SEELIGER 1995). This region accomplishes an area of $971 \mathrm{~km}^{2}$ and water exchange with marine environment occurs through a $20 \mathrm{~km}$ long channel (BONILHA \& ASMUS 1994). Most of the area is composed by muddy and sandy soft bottoms; however, the presence of artificial rocky structures pallasii Brandt, 1833, in Canada and KOOP \& FIELD (1980) verified the influence of the food readiness in the population dynamics of $L$. dilatata Brandt, 1833 , in the South Africa.

Therefore, the present investigation attempts to fill this gap in knowledge, by studying the natural diet of two different populations of $L$. exotica inhabiting distinct sites in the Patos Lagoon estuary. (e.g. $5 \mathrm{~km}$ long breakwater on both sides of channel connecting the estuary to the sea) can be observed (CAPÍTOLLI 1998). Studied areas were two artificial rocky structures: West Breakwater (32ำ15,987'S; $52^{\circ} 09,783^{\prime} \mathrm{W}$ - connecting the estuary to marine

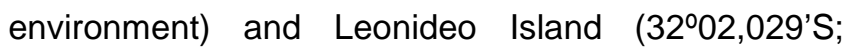
$52^{\circ} 11,951$ ' W - inner estuarine zone) (Figure 1).

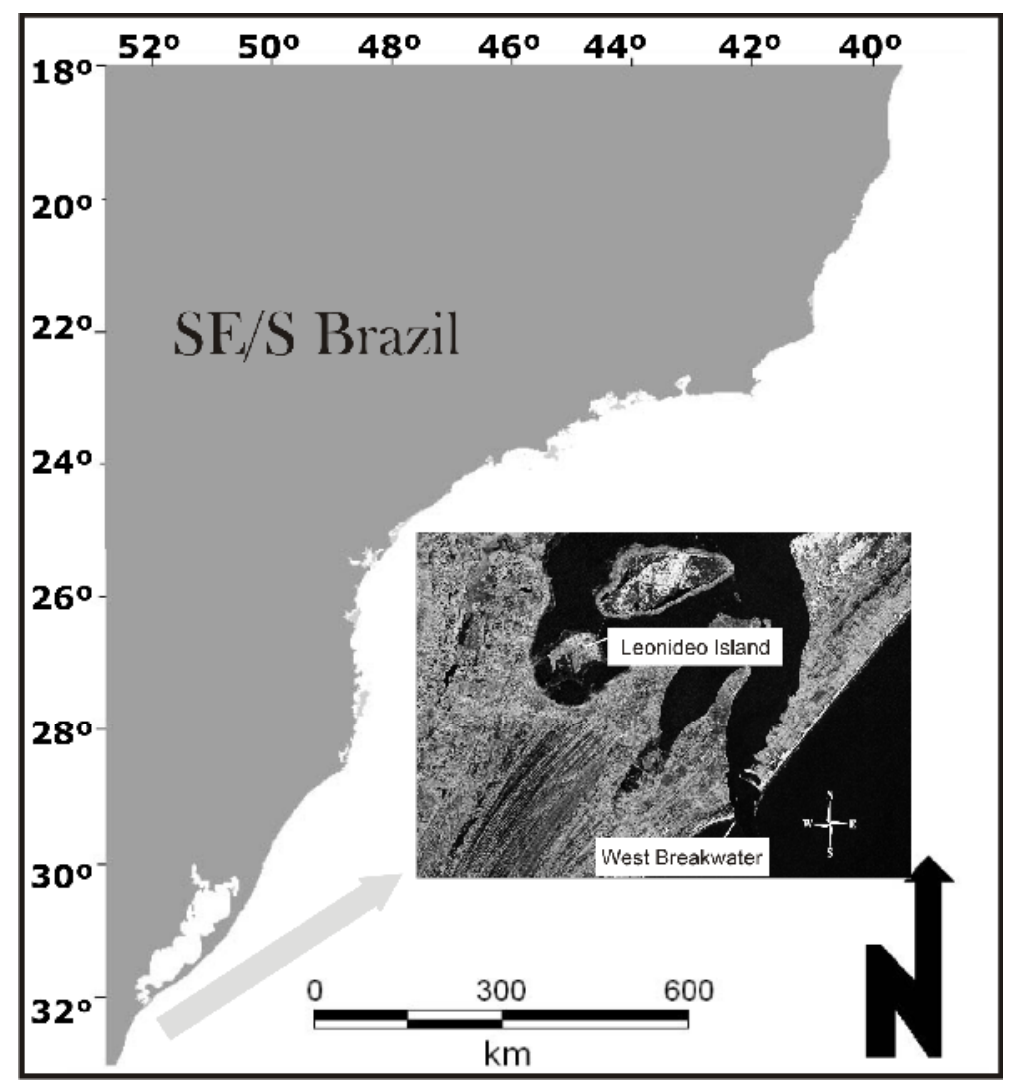

FIGURE 1 - Southeastern and southern Brazil, highlighting the estuarine zone of Patos Lagoon where both populations of $L$. exotica were estudied. Population from West Breakwater is located close to marine environment and therefore subject to higher salinity water. On the other hand, population established on Leonideo Island is located at inner area of the estuary, where salinity is consistently lower.

Samples were collected in October/2003, January, April and July/2004. Individuals of the different age classes were manually collected in the morning by three researchers, during a standard period of one 
hour. Individuals were immediately fixed in $4 \%$ formalin during 24 hours to stop the digestion process and conserved in $70 \%$ alcohol. In the laboratory, the total length, the total weight and the sex were registered.

The extracted guts had the weight and repletion degrees (amount of food present inside) estimated, visually, according to SANTOS (1978) and WEAR \& HADDON (1987) and classified into the following classes: (0) empty, (1) $0.1-30 \%$, (2) $30.1-70 \%$ and (3) $70.1-100 \%$. The content of each gut was diluted in $1 \mathrm{ml}$ of distilled water. The identification and quantification of the items were made through optical microscope with a digital image capture system. The non identifiable items were considered "No Identified Material" (NIM). For the quantification of the items, the gut content was put in a counting cell blade (Sedgewick Rafter, plastic). Each

\section{RESULTS}

A total of 912 individuals were analyzed (432 males and 480 females) during the sampling period. In the West Breakwater a total of 426 individuals was analyzed (215 males and 211 females), while in the Leonideo Island a total of 485 individuals was used (217 males and 268 females). The West Breakwater population (426 guts) showed 32 (7.5\%) empty guts and $394(92.5 \%)$ containing some food. On the other hand, identified item was quantified through the number of occurrences inside squares.

To test possible significant differences between the frequencies of occurrence of the items consumed by males and females, the chi-square test was used to the level of $5 \%$ of significance and $n-1$ degrees of freedom $(n=2)$ (LUDWIG \& REYNOLDS 1998). The linear regression and correlation Pearson's analysis (ZAR 1999) was performed to verify the correlation between the individual's body weight and weight of the guts.

The mean degree of repletion (Gr) and the mean index of repletion (Ir) were estimated according to SANTOS (1978). The qualiquantitative analyses were made by the method of relative frequency of occurrence and relative frequency of points (WILLIAMS 1981; WEAR \& HADDON 1987; OLIVEIRA et al. 2006).

the Leonideo Island population (485 guts) showed 64 $(13,2 \%)$ empty and $421(86,8 \%)$ contained food.

The linear regression and the correlation Pearson's analysis between the total weight of individuals and the total weight of the gut examined for each degree of repletion (Figures 2-3). The parameters observed in both analyses were showed in the Tables 1-2. 

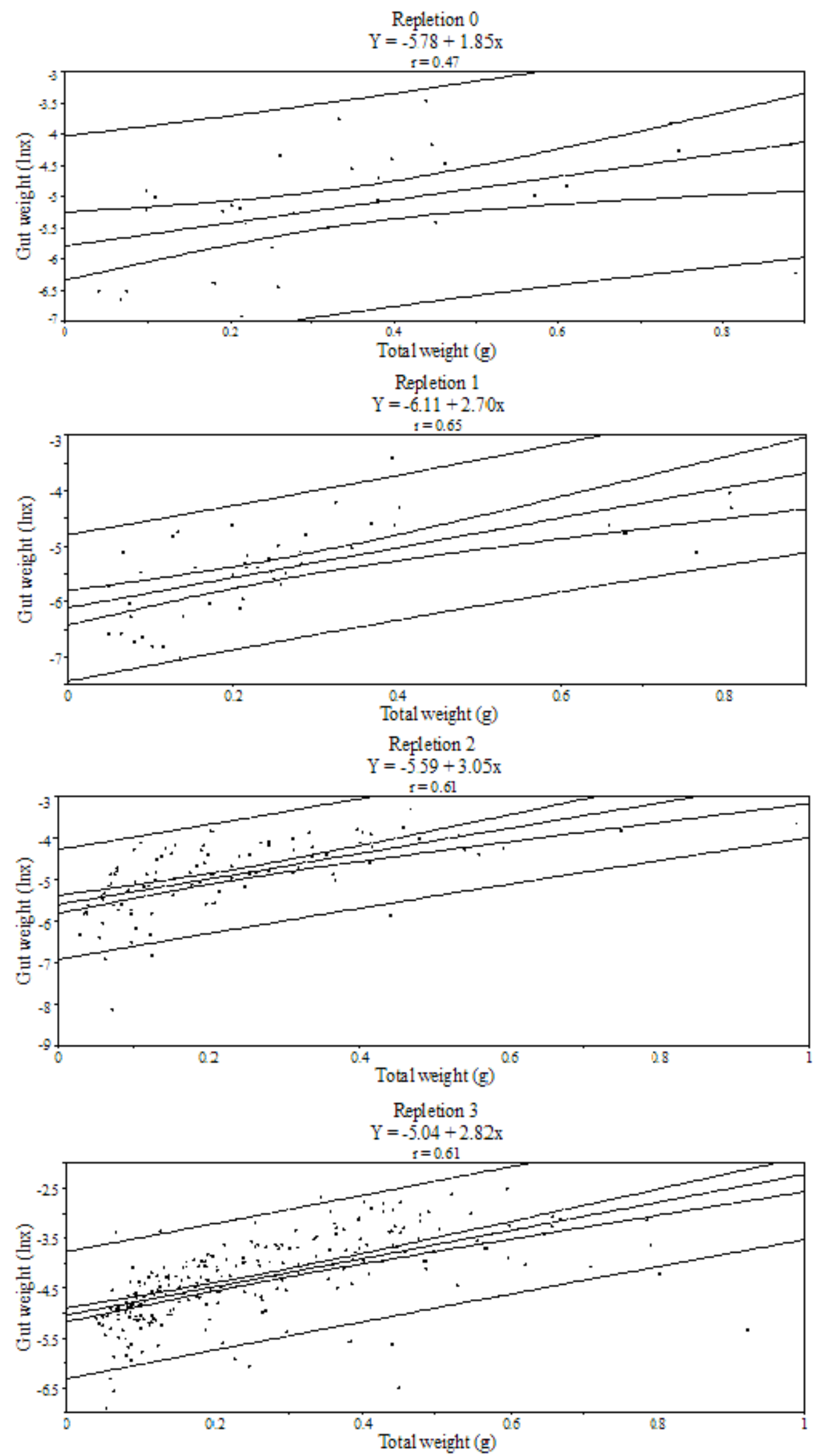

FIGURE 2 - Linear regression between the total weight of individuals and the total weight of the guts by degree of repletion for population of Ligia exotica inhabiting the West Breakwater, Rio Grande do Sul, Brazil. 

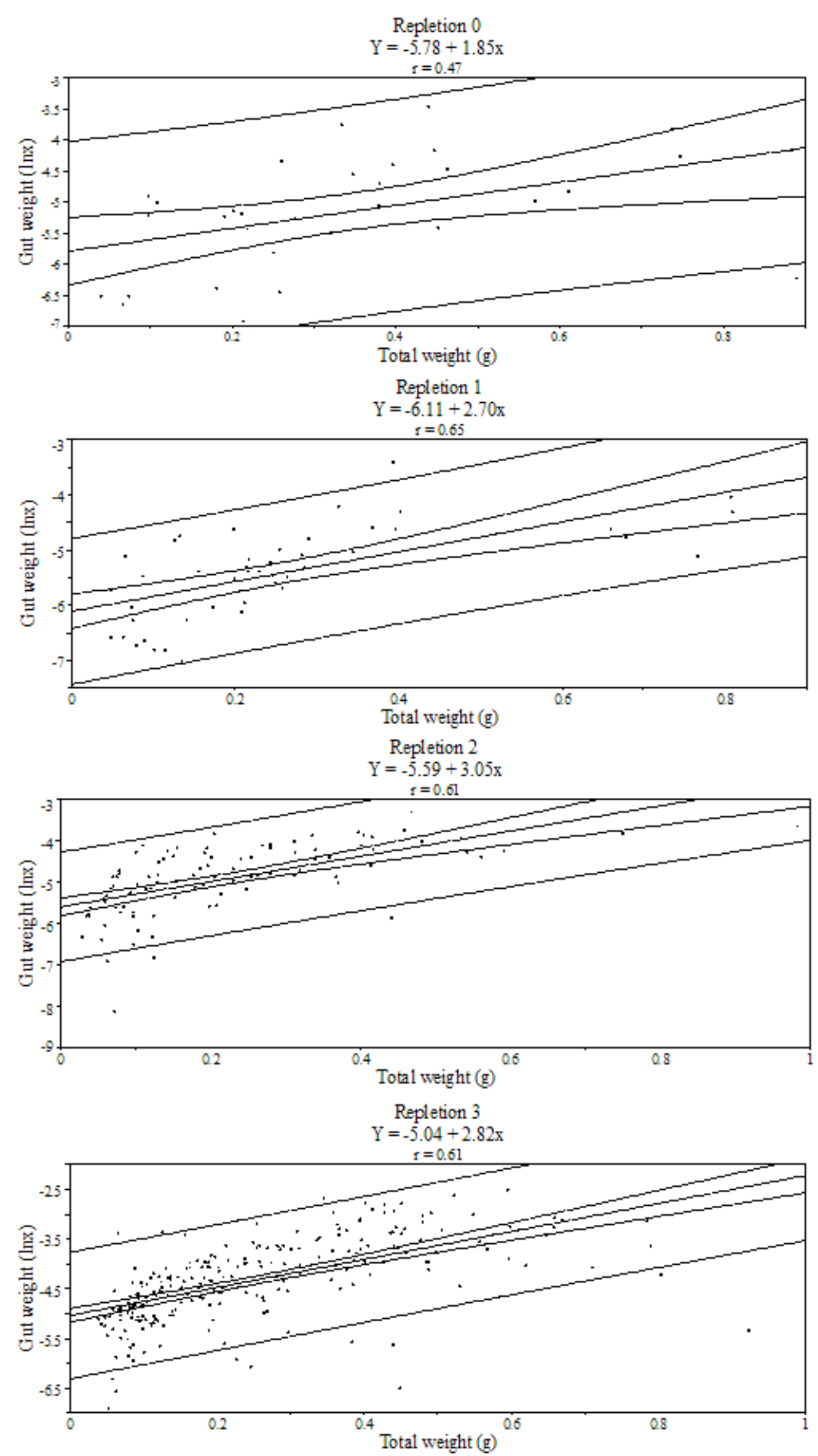

FIGURE 3 - Linear regression between the total weight of individuals and the total weight of the guts by degree of repletion for population of Ligia exotica inhabiting the Leonideo Island, Rio Grande do Sul, Brazil. 
TABLE 1 - Parameters observed in the linear regression and the correlation Pearson's analysis between the total weight of individuals and the total weight of the guts of the analyzed populations of Ligia exotica of the West Breakwater, Patos Lagoon estuary, Rio Grande do Sul, Brazil.

\begin{tabular}{lccccccc}
\hline & $\mathrm{r}$ & $\mathrm{a}$ & 95\% confidence limits & $\mathrm{p}$ & $\mathrm{b}$ & 95\% confidence limits & $\mathrm{p}$ \\
\hline Repletion 0 & 0.4659 & -5.7838 & $-5.2396-6.3279$ & 0.0000 & 1.8484 & 3.15720 .5395 & 0.0072 \\
Repletion 1 & 0.6482 & -6.1111 & $-5.7994-6.4228$ & 0.0000 & 2.7028 & 3.66681 .7379 & 0.0000 \\
Repletion 2 & 0.6132 & -5.5864 & $-5.3698-5.8029$ & 0.0000 & 3.0547 & 3.83942 .2700 & 0.0000 \\
Repletion 3 & 0.6121 & -5.0387 & $-4.8971-5.1804$ & 0.0000 & 2.8243 & 3.28342 .3651 & 0.0000 \\
\hline
\end{tabular}

TABLE 2 - Parameters observed in the linear regression and the correlation Pearson's analysis between the total weight of individuals and the total weight of the guts of the analyzed populations of Ligia exotica of the Leonideo Island, Patos Lagoon estuary, Rio Grande do Sul, Brazil.

\begin{tabular}{lccccccc}
\hline & $\mathrm{r}$ & $\mathrm{a}$ & 95\% confidence limits & $\mathrm{p}$ & $\mathrm{b}$ & 95\% confidence limits & $\mathrm{p}$ \\
\hline Repletion 0 & 0.6804 & -6.8262 & $-6.5120-7.1403$ & 0.0000 & 6.4077 & 8.14504 .6704 & 0.0000 \\
Repletion 1 & 0.6670 & -6.5278 & $-6.3090-6.7466$ & 0.0000 & 5.1015 & 5.92574 .2772 & 0.0000 \\
Repletion 2 & 0.7257 & -6.4364 & $-6.1617-6.7110$ & 0.0000 & 5.5945 & 6.68664 .4024 & 0.0000 \\
Repletion 3 & 0.7693 & -5.8670 & $-5.6922-6.0418$ & 0.0000 & 5.1838 & 5.91374 .458 & 0.0000 \\
\hline
\end{tabular}

The degree of repletion ( $\mathrm{Gr}$ ) and the index of repletion (Ir) showed the same pattern, for males and females of both populations (Figures 4-5), evidencing a reduction in the food ingestion in July, with an increase of the consumption starting from the October.

\section{$\rightarrow$ West Breakwater $\delta \rightarrow$-Island $\delta \multimap$ West Breakwater $\rho \rightarrow$ - Island $\rho$}

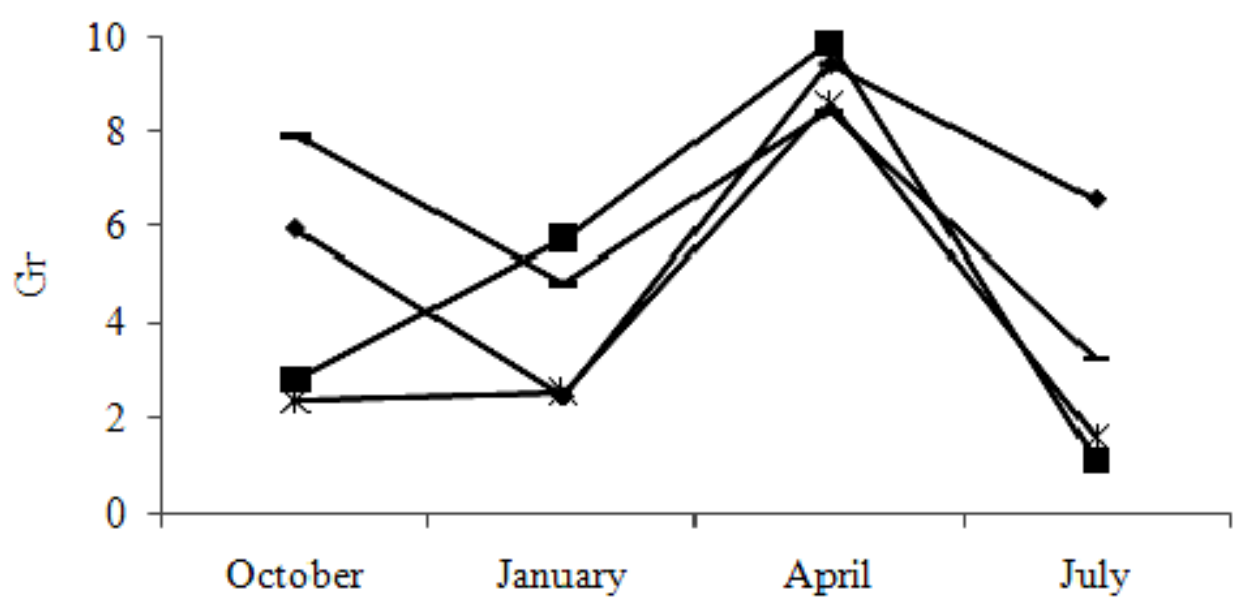

FIGURE 4 - Mean repletion degree (Gr) of the gut contents for males and females of Ligia exotica inhabiting the estuarine region of the Patos Lagoon estuary, Rio Grande do Sul, Brazil. 

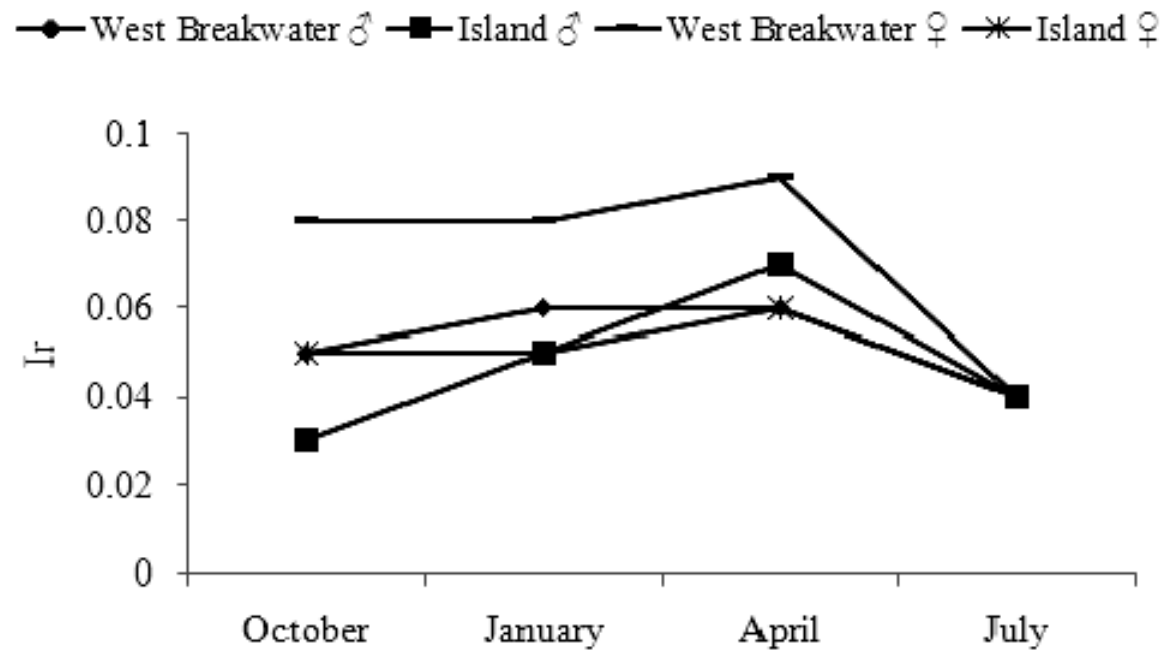

FIGURE 5 - Mean index of repletion (Ir) of the gut contents for males and females of Ligia exotica inhabiting the estuarine region of the Patos Lagoon estuary, Rio Grande do Sul, Brazil.

Six items were observed at West Breakwater population guts: vegetal detritus (VD), the seaweed Polysiphonia sp. (POLY), crustaceans (C), other invertebrates (I), sand grains (SAND) and no identified material (NIM). At the population inhabiting Leonideo Island the only item which has not been found was the other invertebrate (I). Some of the items observed are recorded in Figure 6.
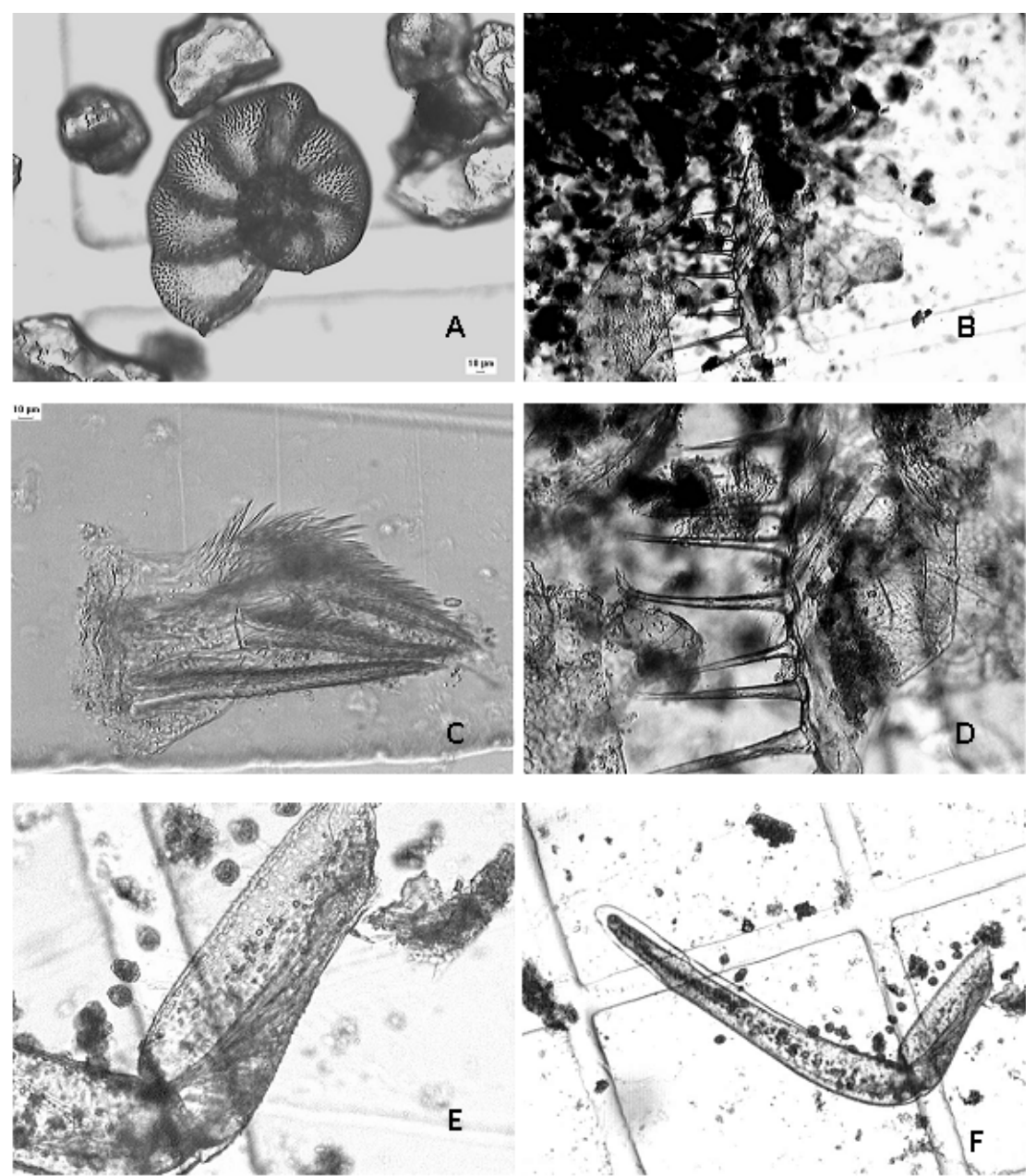

FIGURE 6 - Items observed on the guts of Ligia exotica inhabiting the estuarine region of the Patos Lagoon estuary. A. foraminifera and sand grains; B, C and D. crustaceans shells; E. isopod pereiopod; F. pereiopod of a juvenile isopod. 
The chi-square test showed significant differences for the proportion of the items consumed by males and females from both populations (Tables 3-4). In the West Breakwater, males and females consumed the same items in April and July. In October, the difference in the feeding is related to the consumption of other invertebrates by the males. In
January, all of the observed items, present differentiated consumptions among sexes. In the Leonideo Island, practically all items present different consumptions among the sexes, during January and April. Males and females received the same food items only in October.

TABLE 3 - Absolute frequency (FOa) and relative frequency (FOr) of the items consumed by Ligia exotica in the West Breakwater Channel, of the Patos Lagoon estuary. Significative chi-square values $(p<0,05)$ in bold.

\begin{tabular}{|c|c|c|c|c|c|c|c|c|c|c|}
\hline & \multicolumn{5}{|c|}{ October/2003 } & \multicolumn{5}{|c|}{ January/2004 } \\
\hline & \multicolumn{2}{|c|}{ Males } & \multicolumn{2}{|c|}{ Females } & \multirow[b]{2}{*}{$x^{2}$} & \multicolumn{2}{|c|}{ Males } & \multicolumn{2}{|c|}{ Females } & \\
\hline & FOa & For & FOa & FOr & & $\mathrm{FOa}$ & FOr & $\mathrm{FOa}$ & FOr & $x^{2}$ \\
\hline Vegetal detritus & 93 & 58.5 & 66 & 41.5 & 2.88 & 13 & 36.1 & 23 & 63.9 & 7.72 \\
\hline Polysiphonia sp. & 93 & 58.5 & 66 & 41.5 & 2.88 & 13 & 36.1 & 23 & 63.9 & 7.72 \\
\hline Crustaceans & 55 & 53.4 & 48 & 46.6 & 0.46 & 06 & 31.6 & 13 & 68.4 & 13.57 \\
\hline Invertebrates & 14 & 100.0 & 0 & 0.0 & 100.0 & 02 & 100.0 & 0 & 0.0 & 100.0 \\
\hline Sand & 93 & 58.5 & 66 & 41.5 & 2.88 & 13 & 36.1 & 23 & 63.9 & 7.72 \\
\hline \multirow[t]{4}{*}{ NIM } & 69 & 55.6 & 55 & 44.4 & 1.27 & 08 & 32.0 & 17 & 68.0 & 12.96 \\
\hline & \multicolumn{5}{|c|}{ April/2004 } & \multicolumn{5}{|c|}{ July/2004 } \\
\hline & \multicolumn{2}{|c|}{ Males } & \multicolumn{2}{|c|}{ Females } & & \multicolumn{2}{|c|}{ Males } & \multicolumn{2}{|c|}{ Females } & \\
\hline & FOa & FOr & $\mathrm{FOa}$ & FOr & $x^{2}$ & $\mathrm{FOa}$ & FOr & $\mathrm{FOa}$ & FOr & $x^{2}$ \\
\hline Vegetal detritus & 54 & 42.2 & 74 & 57.8 & 2.44 & 35 & 49.3 & 36 & 50.7 & 0.02 \\
\hline Polysiphonia sp. & 54 & 42.2 & 74 & 57.8 & 2.44 & 35 & 49.3 & 36 & 50.7 & 0.02 \\
\hline Crustaceans & 44 & 44.0 & 56 & 56.0 & 1.44 & 23 & 54.8 & 19 & 45.2 & 0.91 \\
\hline Sand & 54 & 42.2 & 74 & 57.8 & 2.44 & 35 & 49.3 & 36 & 50.7 & 0.02 \\
\hline NIM & 41 & 42.3 & 56 & 57.7 & 2.39 & 25 & 56.8 & 19 & 43.2 & 1.86 \\
\hline
\end{tabular}

TABLE 4 - Absolute frequency (FOa) and relative frequency (FOr) of the items consumed by Ligia exotica in the Leonideo Island, of the Patos Lagoon estuary. Significative chi-square values $(p<0,05)$ in bold.

\begin{tabular}{|c|c|c|c|c|c|c|c|c|c|c|}
\hline & \multicolumn{5}{|c|}{ October/2003 } & \multicolumn{5}{|c|}{ January/2004 } \\
\hline & \multicolumn{2}{|c|}{ Males } & \multicolumn{2}{|c|}{ Females } & \multirow[b]{2}{*}{$x^{2}$} & \multicolumn{2}{|c|}{ Males } & \multicolumn{2}{|c|}{ Females } & \\
\hline & $\mathrm{FOa}$ & FOr & FOa & FOr & & $\mathrm{FOa}$ & FOr & $\mathrm{FOa}$ & FOr & $x^{2}$ \\
\hline Vegetal detritus & 59 & 57.8 & 43 & 42.2 & 2.46 & 24 & 39.3 & 37 & 60.7 & 4.54 \\
\hline Polysiphonia sp. & 59 & 57.8 & 43 & 42.2 & 2.46 & 24 & 39.3 & 37 & 60.7 & 4.54 \\
\hline Crustaceans & 17 & 45.9 & 20 & 54.1 & 0.66 & 23 & 40.4 & 34 & 59.6 & 3.72 \\
\hline Sand & 59 & 57.8 & 43 & 42.2 & 2.46 & 24 & 39.3 & 37 & 60.7 & 4.54 \\
\hline \multirow[t]{4}{*}{ NIM } & 30 & 50.0 & 30 & 50.0 & 0.00 & 14 & 43.8 & 18 & 56.3 & 1.56 \\
\hline & \multicolumn{5}{|c|}{ April/2004 } & \multicolumn{5}{|c|}{ July/2004 } \\
\hline & \multicolumn{2}{|c|}{ Males } & \multicolumn{2}{|c|}{ Females } & & \multicolumn{2}{|c|}{ Males } & \multicolumn{2}{|c|}{ Females } & \\
\hline & $\mathrm{FOa}$ & FOr & FOa & FOr & $x^{2}$ & $\mathrm{FOa}$ & FOr & $\mathrm{FOa}$ & FOr & $x^{2}$ \\
\hline Vegetal detritus & 32 & 38.1 & 52 & 61.9 & 5.66 & 74 & 42.5 & 100 & 57.5 & 2.23 \\
\hline Polysiphonia sp. & 32 & 38.1 & 52 & 61.9 & 5.66 & 74 & 42.5 & 100 & 57.5 & 2.23 \\
\hline Crustaceans & 17 & 25.0 & 51 & 75.0 & 25.00 & 25 & 40.3 & 37 & 59.7 & 3.75 \\
\hline Sand & 32 & 38.1 & 52 & 61.9 & 5.66 & 74 & 42.5 & 100 & 57.5 & 2.23 \\
\hline NIM & 08 & 22.9 & 27 & 77.1 & 29.47 & 29 & 38.2 & 47 & 61.8 & 5.61 \\
\hline
\end{tabular}


For the two populations analyzed, the most important items in terms of relative frequency of occurrence and relative frequency of the points
(Figures 7-8) were the vegetal detritus and the seaweed Polysiphonia sp. The sand grains showed an important presence at guts too.

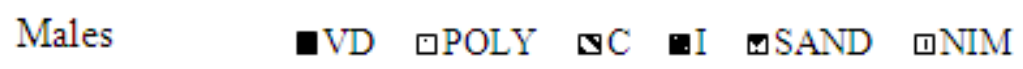

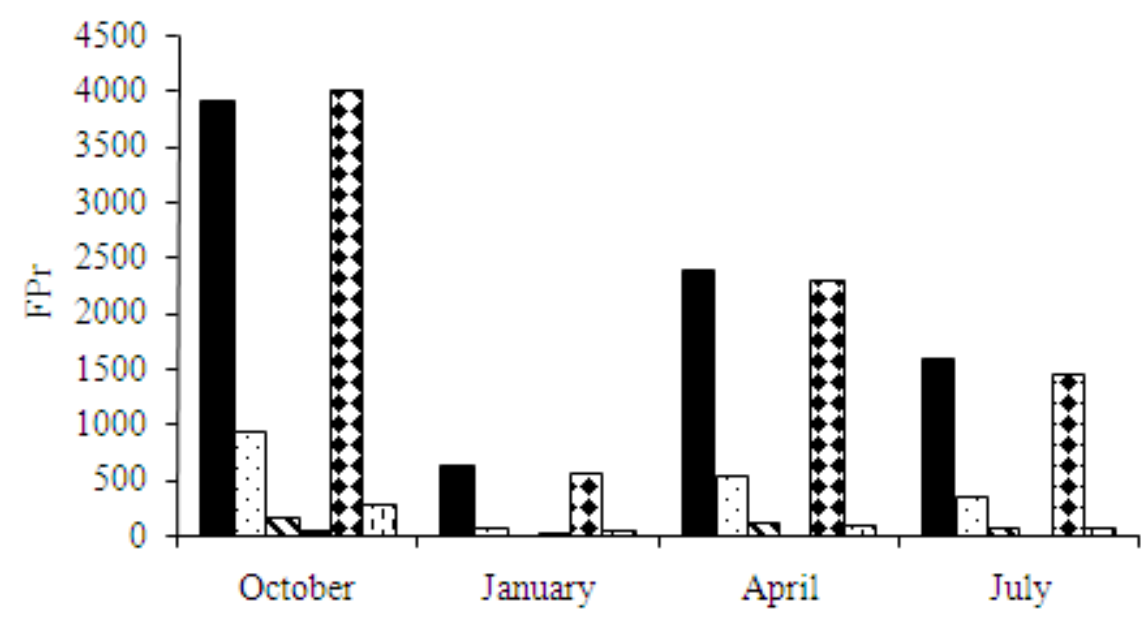

Females $\quad \mathbf{V D} \quad \square \mathrm{POLY} \quad \mathbf{\mathrm { C }} \quad \boldsymbol{\mathrm { SAND }} \quad \mathrm{QNIM}$

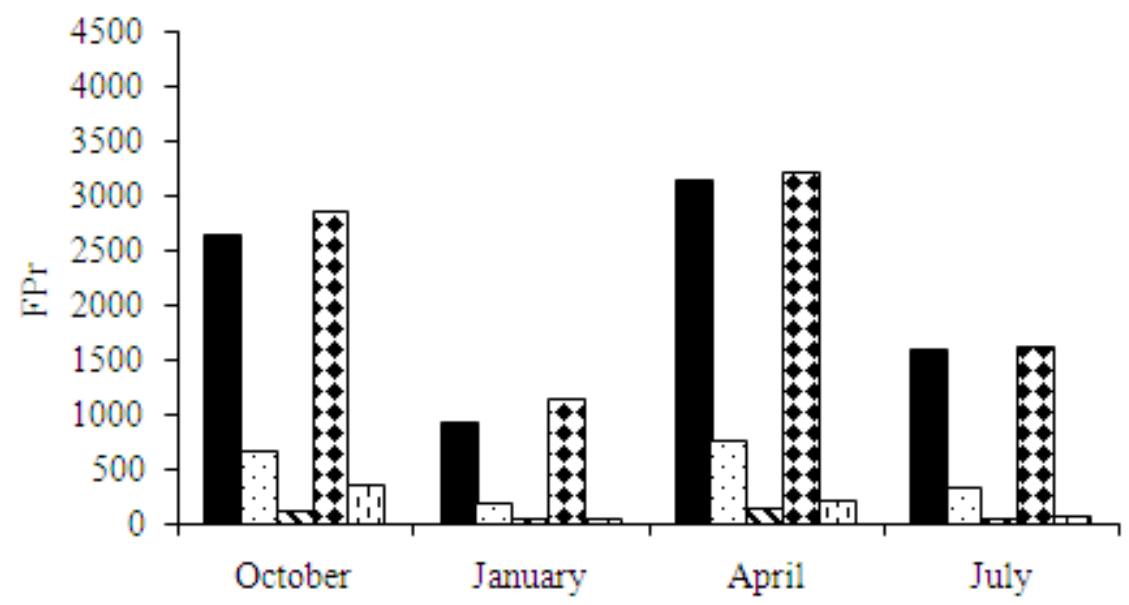

FIGURE 7 - Relative frequency of points (FPr) of the guts contents estimated for males and females of $L$. exotica inhabiting the West Breakwater, Rio Grande do Sul, Brazil. (VD = vegetal detritus; POLY = seaweeds Polysiphonia sp.; C = crustaceans; I = other invertebrates; SAND = sand grans; NIM = no identified material). 

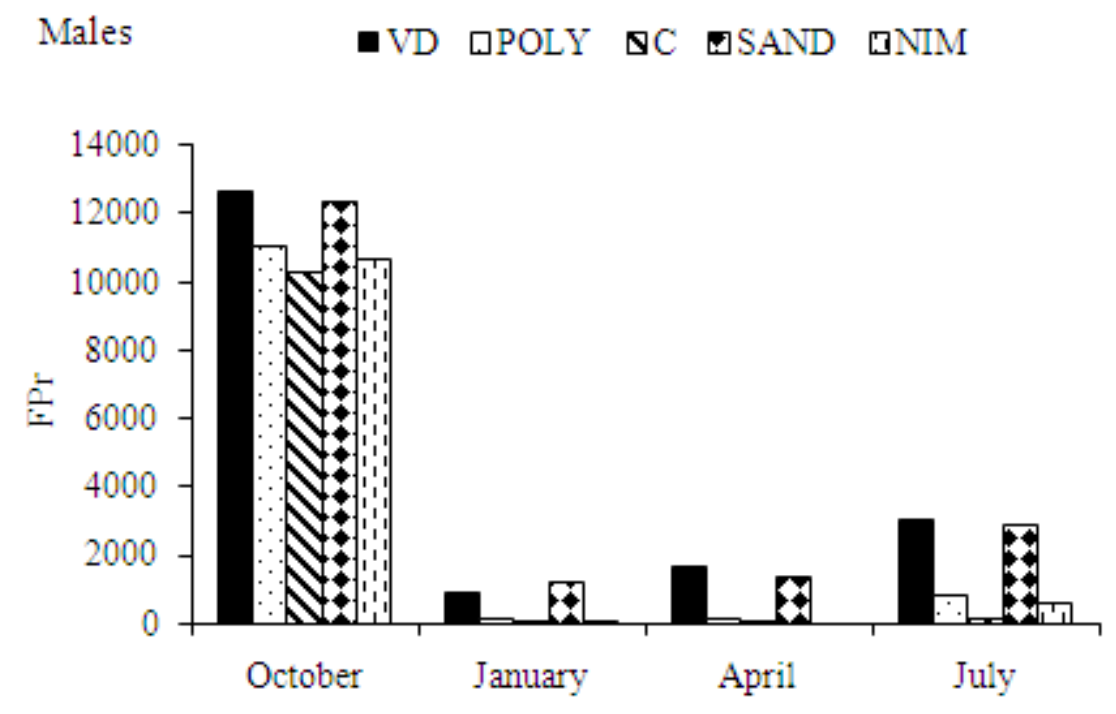

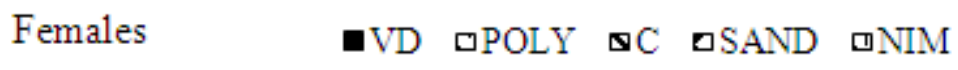

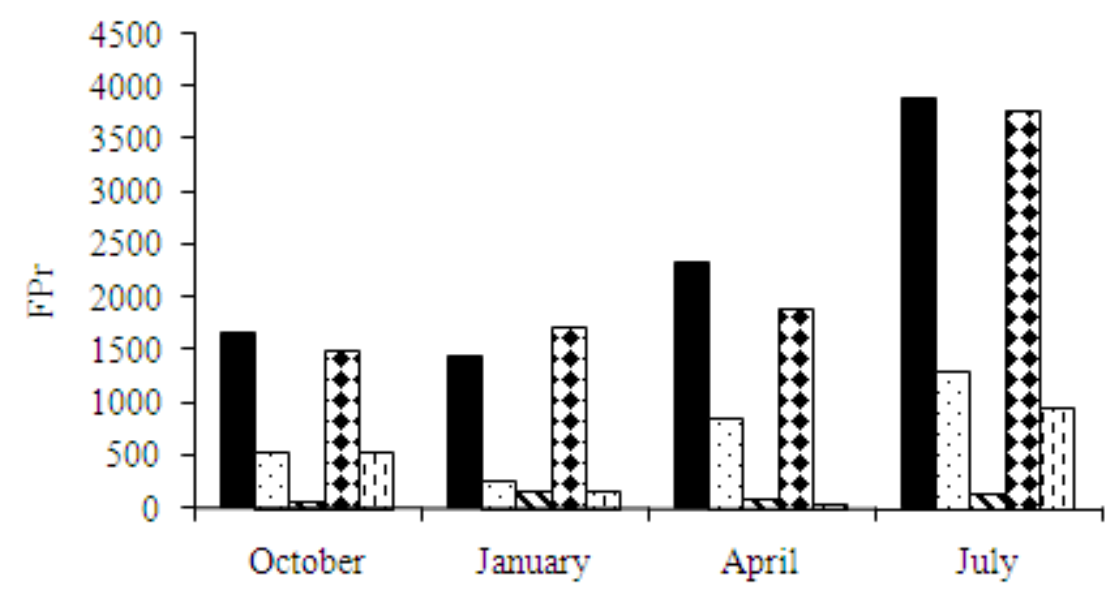

FIGURE 8 - Relative frequency of points (FPr) of the guts contents estimated for males and females of $L$. exotica inhabiting the Leonideo Island, Rio Grande do Sul, Brazil. (VD = vegetal detritus; POLY = seaweeds Polysiphonia sp.; C = crustaceans; SAND = sand grans; NIM = no identified material).

The natural diet of Ligia exotica at the Patos Lagoon estuary consists of vegetal and seaweeds. The ingestion of sand happened together with the other items, indicating the scrape habit of this species.

\section{DISCUSSION}

The analysis of gut contents from the two populations of Ligia exotica, allows to consider the occurrence of significant differences in the relative quantity of food consumed by males and females. In the West Breakwater population, the difference is due to the consumption of invertebrate animals by the
The consumption of animal items occurred in an occasional way, very likely, due to the little abundance of vegetal food. 
reproductive season of the species. Before copulate, the females accomplish a reproductive molt for the development of marsupium and stop feeding, they are totally inactive. However, it is probable that after the young births, the females feed actively, to recover energy wasted in reproduction (SUTTON 1980).

The females from Leonideo Island feed more frequently on crustaceans than the males, probably, due to the occupation of different microhabitats by the smaller individuals. SUTTON (1980) cited that the calcium absorption is mainly done by the exuvium ingestion and predation over the juveniles of its own species. NUMANOI (1934) estimated that $25 \%$ of the calcium contained in the exoskeleton of Ligia exotica is lost through the molting process, but if the species ingests the exuvium, this loss can become low.

Changes in the diet of the species during the sampling period were not observed. Vegetal detritus, seaweeds and sediment were the more present items into the guts during the whole period. During the hottest months, the occurrence an increase of items with animal origin was observed, probably related to the higher availability of those organisms in the environment at that moment.

CAREFOOT (1973) observed that Ligia pallasii has a diet composed by diatom algae, insect larvae and juvenile of its own species. In the shortage of these items, the species can feed on the algae Ulva sp. or other most accessible algae. CAREFOOT (1984) registered that $L$. pallasii feeds on diatoms and algae but, occasionally, feed on material of animal origin. CAREFOOT (1989) affirms that the feeding of the genus Ligia species consists, basically, in diatoms, small filamentous algae and macroalgae. However, some small animals can also be consumed.

For Ligia exotica, the items more frequently consumed were vegetal detritus and sediment. Polysiphonia sp. appears with great frequency during the month of October. For CAREFOOT et al. (1998, 2000), species of the genus Ligia are nocturnal and emerge from their hiding places during the night to feed over benthic macroalgae and diatoms. They are also found foraging other algae in the top of the intertidal zone.

The genus presents a detritivorous feeding habit. Since this species represents a transition between the sea and land, Ligia can contain tracks of an ancestral diet of sea plants (CAREFOOT 1987a). Some species feed on fragments of kelps brought by the tide, which are known as the favorite food item for this. In laboratory and in nature these fragments promote the growth and the survival of the species (CAREFOOT 1984; KOOP \& FIELD 1980; PENNINGS et al. 2000).

The small inter and intra-population variations observed in the composition and percentages of items consumed by Ligia exotica in the period sampled are probably due to the environmental richness of food. KOOP \& FIELD (1980) consider the life history of the organisms, capable to use protected microhabitats at the supralittoral, more dependent of biological factors, such as the availability of food, than physical factors.

Face to the characteristics presented by Ligia exotica regarding its food behavior, this species can be considered a detritivorous feeder, influenced by the availability of food in the environment that it inhabits.

\section{ACKNOWLEDGEMENT}

This research was supported by CAPES (Ministry of Education, Brazil) through a PhD. studenship to Elis R. Lopes-Leitzke.

\section{REFERENCES}

BONILHA, LE. \& ML ASMUS. 1994. Modelo ecológico do fitoplâncton e zooplâncton do estuário da Lagoa dos Patos, R.S. Publicações da Academia de Ciências do Estado de São Paulo, 87(1): 347-362.

CAPÍTOLLI, R. 1998. Substratos Consolidados. In Os Ecossistemas Costeiro e Marinho do Extremo Sul do Brasil (SEELIGER, U., C ODEBRECHT \& JP CASTELLO, Eds), Rio Grande: Ecoscientia. pp. 96-99.

CAREFOOT, TH. 1973. Feeding, food preference and uptake of food energy by the supralittoral isopod Ligia pallasii. Mar. Biol., 18: 228-236.

CAREFOOT, TH. 1984. Studies on the nutrition of the supralittoral isopod Ligia pallasii using chemically defined artificial diets: assessment of vitamin, carbohydrate, fatty acid, cholesterol and mineral requirements. Comp. biochem. physiol. part A, 79(4): 655-665.

CAREFOOT, TH. 1987a. The effect of diet quality on oxygen consumption in the supralittoral isopod Ligia pallasii. Comp. biochem. physiol. part A, 87(1): 127-134.

CAREFOOT, TH. 1987b. Diet and metabolic rate in the supralittoral isopod Ligia pallasii: the effect on oxygen uptake of ration levels of natural and chemical diets. Comp. biochem. physiol. part A, 87(4): 989-992.

CAREFOOT, TH. 1989. Diet and its effect on oxygen consumption in the semiterrestrial isopod Ligia. Monit. Zool. Ital. (N.S.) Monogr., 4: 193-210.

CAREFOOT, TH. \& BE TAYLOR. 1995. Ligia: A prototypal 
terrestrial isopod. In Crustacean Issues (SCHARM, FR, ed), Rotterdam. pp. 47-60.

CAREFOOT, TH., BE TAYLOR, S KALWA, G SOMOGYI \& B HUGHES. 1992. Effect of dietary d-amino acids on growth, survival, ammonia excretion and specific dynamic action in the supralittoral isopod, Ligia pallasii. Comp. biochem. physiol. part A, 103(3): 559-563.

CAREFOOT, TH., BE TAYLOR \& K BRETT. 1998. A day in the life of an isopod: time and energy allocations in the semiterrestrial Ligia pallasii. Isr. J. Zool., 44: 463-471.

CAREFOOT, TH., J WRIGHT, SC PENNINGS, A ZIEGLER, M ZIMMER, RF UGLOW, AR DANFORD \& JP DANKO. 2000. Hemolymph homeostasis in relation to diel feeding activity and microclimate in the prototypal land Ligia pallasii. Canad. J. Zool., 78: 588-595.

CORDAZZO, CV. \& U SEELIGER. 1995. Guia ilustrado da vegetação costeira no extremo sul do Brasil. Rio Grande, Editora da FURG, 275p.

ERHARDT, F. 1997. The pleonal skeleton and musculature of Titanethes albus (Synochaeta) and of further taxa of the Oniscidea (Isopoda), with conclusions on the phylogeny of terrestrial isopods. Stut. Beit. Natur. Serie A.,550: 1-70.

KOOP, K. \& JG FIELD. 1980. The influence of food availability on population dynamics of a supralittoral isopod, Ligia dilatata Brandt. J. Exp. Mar. Biol. Ecol., 48(1): 61-72.

LEMOS DE CASTRO, A. 1971. Isópodos terrestres introduzidos no Brasil (Isopoda, Oniscoidea). Bol. Mus. Nac., 282: 1-14.

LOPES-LEITZKE, E.R., LFC DUMONT, \& F D'INCAO. 2009. Growth of Ligia exotica Roux, 1828 (Isopoda, Oniscidea, Ligiidae) in two estuarine regions of Patos Lagoon, Rio Grande do Sul, Brazil. J. Mar. Biol. Assoc. UK., 89(4): 735-741.

LUDWIG, JA. \& JF REYNOLDS. 1998. Statistical ecology: a primer on methods and computing. New York, John Wiley \& Sons, 338p.

NUMANOI, H. 1934. Effect of temperature on the frequency of the rhythmical beatings of the pleopods of Ligia exotica. J. Fac. Sci. Imp. Univ. Tokyo, 3: 217-225.

OLIVEIRA, A., TK PINTO, DPD SANTOS \& F D'INCAO. 2006. Dieta natural do siri-azul Callinectes sapidus (Decapoda, Portunidae) na região estuarina da Lagoa dos Patos, Rio Grande, Rio Grande do Sul, Brasil. Iheringia, Sér. Zool., 96(3): 305-313.

PENNINGS, SC., TH CAREFOOT, Z ZIMMER, JP DANKO \& A ZIEGLER. 2000. Feeding preferences of supralittoral isopods and amphipods. Canad. J. Zool., 78: 1918-1929.

SANTOS, EP. 1978. Dinâmica de populações aplicada à pesca e piscicultura. São Paulo, Editora da USP, 129p.

SCHMALFUSS, H. 2003. World catalog of terrestrial isopods (Isopoda: Oniscidea). Stutt. Beit. Natur. Ser. A, 654: 1-341.

SCHULTZ, GA. 1977. Terrestrial isopods crustaceans (Oniscoidea) from St. Catherines Islands. Geor. J. Sci., 35: 151-158.

SHEADER, M. 1977. The breeding biology of Idotea pelagica (Isopoda: Valvifera) with notes of the occurrence and biology of its parasite Clypeoniscus hanseni (Isopoda: Epicaridea). J. Mar. Biol. Assoc. UK., 57: 659-674.

SOUZA, GD. 1998. Biologia reprodutiva de Ligia exotica (Crustacea, Isopoda, Ligiidae) no Molhe do Rio Tramandaí, Imbé, Rio Grande do Sul, Brasil. Iheringia, Sér. Zool., 84: 101-108.

SOUZA-KURY, LA. 1998. Malacostraca-Peracarida. Isopoda. Oniscidea. In Catalogue of Crustacea of Brazil. (YOUNG, PS, ed), Rio de Janeiro: Museu Nacional/UFRJ. pp. 653-674.

SUTTON, SL. 1980. Woodlice. Oxford, Perganon Press, 143p.

WEAR, RG. \& M HADDON. 1987. Natural diet of the crab Ovalipes catharus (Crustacea, Portunidae) around central and northern New Zealand. Mar. Ecol. Prog. Ser., 35: 39-49.

WILLIAMS, MJ. 1981. Methods for analysis of natural diet in portunid crab (Crustacea: Decapoda: Portunidae). J. Exp. Mar. Biol. Ecol., 52: 103-113.

ZAR, JH. 1999. Biostatistical Analysis. New Jersey, Prentice-Hall, 931p

Submetido: 06/01/2010

Aceito - 07/12/2011 